DE9 1007189

\title{
EFFECTS OF IRRADIATION ON CRACK-ARREST TOUGHNESS OF TWO HIGH-COPPER WEIDS*
}

S. K. Iskander, W. R. Corwin, and R. K. Nanstad

Metals and Ceramics Division

OAK RIDGE NATIONAL LABORATORY

Oak Ridge, Tennessee 37831-6151

*Research sponsored by the Office of Nuclear Regulatory Research, U.S. Nuclear Regulatory Corinission, under Interagency Agreement DOE 1886-8109-8L with the U.S. Department of Energy under contract DE-AC05-840R21400 with Martin Marietta Energy Systems, Inc.

The submitied momuscript has beon

outhored by a controcior of the U.S.

Government under controct to DE.

ACO5-8ADA2 1400. ACcordinty

Government rotains

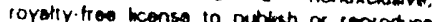

the pubtesthed form of the conistoprion, or

ollow others to do so. for U.S. Government

purpeses." 

irradiation on the shift and shape of the lower-bound curve to crack-arrest data. Two submerged-arc welds with copper contents of 0.23 and 0.31 wt $\&$ were commercially fabricated in $220-\mathrm{mm}$-thick plate. Crack-arrest specimens fabricated from these welds were irradiated at a nominal temperature of $288^{\circ} \mathrm{C}$ to an average fluence of $1.9 \times 10^{19}$ neutrons $/ \mathrm{cm}^{2}(>1 \mathrm{Mev})$. A preliminary evaluation of the results shows that the neutron-irradiation induced crack-arrest toughness temperature shift is about the same as the Charpy V-notch impact temperature shift at the $41-\mathrm{J}$ energy level. The shape of the lower-bound curves, (for the range of test temperatures covered), compared to those of the ASME $\mathrm{K}_{\mathrm{Ia}}$-curve did not seem to have heen altered by irradiation.

KEY WORDS: ASME Boiler and Pressure Vessel Code - Section IIl, Charpy V-notch impact toughness, copper content, crack arrest, crack-arrest toughness, drop-weight, embrittlement, fracture toughness, irradiation, $K_{I a}$, light-water reactors, neutron fluence, 
Effects of Neutron Irrad, on KIa

Nashville Puper

January 15, 1991 12:39pm Page 2

\begin{abstract}
nil-ductility transition temperature, radiation damage, reactor pressure vessels, reference nil-ductility-transition temperature, $\mathrm{RT}_{\mathrm{NDT}}$, regulatory guide, submerged-arc welds, surveillance, transition temperature shift, $\Delta \mathrm{RT}_{\mathrm{NDT}}$.
\end{abstract}




$\mathrm{K}_{\mathrm{a}}$ The value of the stress intensity factor shortly after arrest
$\mathrm{K}_{\mathrm{Ia}} \quad$ The value of the crack-arrest fracture toughness $\mathrm{K}_{\mathrm{a}}$ for a crack that
arrests under conditions of crack front plane-strain
$\mathrm{K}_{\mathrm{Ic}} \quad$ Plane-strain fracture toughness
$\mathrm{K}_{\mathrm{Jc}} \quad$ A measure of fracture toughness calculated frorn the $\mathrm{J}-$ integral $\mathrm{J}_{\mathrm{c}}$ at
the point of cleavage using the relationship $\left(\mathrm{K}_{\mathrm{Jc}}\right)^{2}=\mathrm{EJ}_{\mathrm{c}}$
$\mathrm{T} \quad$ Test temperature
$\mathrm{W}$

1 Excerpted from ASTM E 1221-88. 


\section{INTRODUCTION}

In the fracture mechanics integrity analysis of reactor pressure vessels (RPVs), the initiation and arrest fracture toughness curves as described in Section XI of the ASME Boiler and Pressure Vessel Code are often used. These curves are also used for the normal operation of RPVs. The effects of neutron irradiation on toughness are accounted for by shifting the curves upward in temperature without change in shape by an amount equal to the temperature shift of the Charpy $V$-notch (CVN) impact energy curve at the $41-\mathrm{J}$ level $\left(\Delta \mathrm{TT}_{41-\mathrm{J}}\right)$. Such a procedure implies that the shifts in the fracture toughness curves are the same as that of the CVN $\triangle \mathrm{TT}_{41-J}$, and that irradiation does not change the shapes of the fracture toughness curves.

As is well known, irradiation of some RPV ferritic steels to fluences on the order of $2 \times 10^{19}$ neutrons $/ \mathrm{cm}^{2}(>1 \mathrm{MeV})$ can cause changes in the shape of the CVN impact energy curve. To determine whether similar changes in shape can occur in the fracture toughness curves, particularly if such changes could lead to nonconservative determinations of the irradiated fracture toughness, research programs have been sponsored by the U.S. Nuclear Regulatory Commission (NRC) within the Heavy-Section Steel Irradiation (HSSI) Program.

Two of these programs are the Fifth and Sixth Irradiation Series. The objective of the Fifth Series is to determine the effect of neutron irradiation on the shift and shape of the $K_{I c}$ vs $\left(T-R T_{N D T}\right.$ ) curve, where $K_{I c}$ is the planestrain fracture toughness, $T$ is the temperature, and $\mathrm{RT}_{\mathrm{NDT}}$ is the reference nil- 
ductility transition temperature. The objective of the Sixth Series is similar, but investigates the effect on $\mathrm{K}_{\mathrm{Ia}}$, the plane-strain crack-arrest fracture toughness. Both programs investigate the effects of irradiation on the fracture toughness of welds, since some pressure vessels in operation have welds with copper contents and end-of-life fluences which make them susceptible to severe degradation in toughness. It is noted that the amount of experimental data on the effects of irradiation on crack-arrest fracture toughness is rather meager, [1], [2].

Two submerged-arc welds with copper contents of 0.23 and 0.31 wt $\&$ were commercially fabricated in $220-\mathrm{mm}$-thick plate. In the Fifth Irradiation Series, irradiated CVN impact, tensile, drop-weight and compact specimens made from the weldment were tested and the results are given in Ref.[3] and [4].

Crack-arrest specimens fabricated from these welds were irradiated at a nominal temperature of $288^{\circ} \mathrm{C}$ to an average fluence of $1.9 \times 10^{19}$ neutrons $/ \mathrm{cm}^{2} \quad>1$ Mev). This paper compares the results of crack-arrest tests on 36 irradiated weld-embrittled type specimens with those from unirradiated, control specimens. Since this is only the first phase of a two-phase program, the conclusions presented here are preliminary.

\section{DESCRIPTION OF MATERIALS AND PROCEDURES}

The weld wire for both programs was produced commercially in one melt. The melt was split to allow for copper additions and resulted in two weld wires that 
were comparable in chemical composition except for copper. Several meters of weldment were commercially fabricated from each weld wire and were designated $72 \mathrm{~W}$ $(0.23$ wt $\& \mathrm{Cu})$ and $73 \mathrm{~W}(0.31 \mathrm{wt} \& \mathrm{Cu})$. The welds were commeretally fabricated in A533 grade B class 2 plate of $220-\mathrm{mm}$ ( 8 5/8-in) thickness using the submergedarc weld process with one lot of Linde 0124 flux. A macrograph of weld $72 \mathrm{~W}$ is shown in Fig. 1 and the chemical compositions $n f$ both welds axe given in Table 1. The welds were given a postweld heat treatment of $607^{\circ} \mathrm{C}$ for $40 \mathrm{~h}$, typical of that given commercial RPVs.

Two capsules, each containing 30 compact crack-arrest specimens of the two weldments, have been irradiated at a nominal temperature of $28^{\circ} \mathrm{C}$ to a fluence of approximately $1.9 \times 10^{19}$ neutrons $/ \mathrm{cm}^{2}(>1 \mathrm{MeV})$ in the Oak Ridge Research Reactor located at the Oak Ridge National Laboratory (ORNL). The total. irradiation time was 96 days, thus the average flux is approximately $2.3 \times 10^{12}$ neutrons $\cdot \mathrm{cm}^{-2} \cdot \mathrm{s}^{-1}$. The irradiated specimen complement is given in $\mathbf{T}_{\mathrm{ab}} \mathrm{e} 2$, which gives the overall nominal specimen dimensions. For administrative purposes, the program was conducted in two phases. This paper presents results of phase 1 which consists of crack-arrest tests or the 36 weld-embrittled type specimens. In Phase 2, the remaining 24 duplex type crack-arrest specimeng will be tested.

\section{Testing Procedures}

Testing was performed according to the ASTM Test for Deterinining Plane. Strain Crack-Arrest Fracture Toughness, $K_{I a}$, of Ferritic Steels (E 1.221-88). Crack-arrest testing of the irradiated specimens was performed in a hot cell using a servo-hydraulic machine and the test chamber shown schematically in Fig.

2. It allows specimens to be tested with tha split pins in eitnef the so-called 
"normal" or "inverted" configuration at test temperatures ranging from - 100 to $260^{\circ} \mathrm{C}$. In the "normal" configuration, the lateral surfaces of the specimen are in contact with the test-machine platten and the friction decreases the crackdriving force somewhat compared to the "inverted" configuration in which the specimen sits on narrow shoulders of the split pin. The "inverted" configuration is used at testing temperatures above the NDT temperature. For further information on the "normal" and "inverted" test configuration in crack-arrest testing, see Note 5 of ASTM E 1221-88.

Temperature conditioning below ambient is obtained by venting cold nitrogen gas into the chamber containing the crack-arrest specimen. Above ambient, temperature control is achieved by means of six heater elements. Four of these elements are cartridge type and are embedded in the base of the fixture. Two heater elements are U-shaped and can be moved into place below or above the specimen. After the specimen is positioned in the fixture, a contact thermocouple is lowered onto the specimen surface near the mid-point of the crack path to measure the specimen temperature.

A considerable effort was made to ensure the uniformity of temperature in the crack-arrest specimen as well as its accuracy. Specimens of A533B steel and of the same three sizes as those to be tested were instrumented win thermocouples and thermally conditioned in the fixture over the relevant temperature range in both normal and inverted configurations. The uniformity and accuracy of the temperature throughout the specimen were within $\pm 1{ }^{\circ} \mathrm{C}$ when compared to the values measured by the contact thermocoxple used during testing. 
The clip gage used for the irradiated tests was specially designed and fabricated at ORNL with long arms in order to measure the crack-mouth opening displasement (CMOD) from outside of the temperature conditioning chamber. The clip gage arms are instrumented with temperature-compensated electric resistance strain gages. Moreover, tests outside the hot-cell have shown that the clip gage temperature is less than $35^{\circ} \mathrm{C}$ when the specimen temperature is $350^{\circ} \mathrm{C}$. Since the maximum test temperature is under $150^{\circ} \mathrm{C}$, the $=1$ ip gage is calibrated at room temperature with no significant loss in accuracy. The clip gage was calibrated in the hot-cell with a Boekler Micrometer before and after every test since the CMOD meassured during the test (and not the load!) is central to the determination of the crack-arrest toughness $K_{a}$. The error in $K_{a}$ due to errors in the measurement of CMOD is estimated to be less than $\pm 2 z$.

Analysis Procedures

The arrested crack front was marked by heat-tinting the specimen after testing. The specimen was then cooled with ilquid nitrogen and broken open. The length of the remaining ligament for each specimen was obtained by measuring the position of the arrested crack front using the averaging procedure prescribed in ASTM E 1.21-88. In the case of irradiated specimens, a digitizing tablet is used to measure the length of the remaining ligament on a photograph taken through a Kollmorgan periscope of the broken specimen half. Typical fracture surfaces for: two $25 \times 152-\mathrm{mm}$ specimens are shown in Fig. 3. Numerous unbroken ligaments, typical for pressure vessel steels at these test temperatures, can be observed on the fracture surface of the specimens. The known dimensions of the specimen serve as the scale for these measurements. In the case of unirradiated specimens, the length of the remaining ligament is directly measured by a digital. 
Effects of Neuiron Irrad, on KIa

measuring microscope. The errors due to the measurement method are probably less than those due to the shape of the crack front.

As previously mentioned, the measurement of the final crack length $a_{a}$ is performed according to ASTM E 1221-88 by an averaging procedure. Since it is rare that the arrested crack front is square or straight, see Fig. 3 , it is difficult to estimate the error in such a determination. Using the expression for $K_{a}$ given in ASTM E 1221-88, estimates of the error were made using the maximum valid value of an arrested crack length $e_{a}$ in a small specimen to obtain an upper bound on the error. A value of $a_{a}=54 \mathrm{~mm}$ is the maximum valid length allowed by E 1221-88 for the sma11 $25 \times 76 \times 76 \mathrm{~mm}$ specimen. Errors of \pm 1 or $\pm 2 . \mathrm{mm}$ in $\mathrm{a}_{\mathrm{a}}$ for chis case results in errors of $\mp 6.58$ or $\mp 13 \%$ respectively in $\mathrm{K}_{\mathrm{a}}$. The total maximum error in $\mathrm{K}_{\mathrm{a}}$ from all sources is estimated to be approximately \pm 10 for the small specimens, and \pm 5 for the large ones.

\section{RESULTS AND DISCUSSION.}

The temperature control for the two irradiation capsules, each containing 30 specimens, was excellent. The temperature of the majority of both weldembrittled and duplex-type specimens (22 in one capsule and 23 in the other) ranged from 286 to $290^{\circ} \mathrm{C}$, while the few remaining specimens were irradiated at temperatures ranging from 280 to $286^{\circ} \mathrm{C}$. The average irradiation temperature of al1 60 crack-arrest specimens is approximately $287^{\circ} \mathrm{C}$. For both the $72 \mathrm{~W}$ and $73 \mathrm{~W}$ specimens, the fluences to which the weld-embrittled type crack-arrest specimens were irradiated ranged from approximately 1.4 to $2.4 \times 10^{29} \mathrm{n} / \mathrm{cm}^{2}(>1 \mathrm{MeV})$. For 
Effects of Neutron Irrad. on KIa

- Nashville Paper

January 15, 1991 12:39prn Page 11

both the $72 \mathrm{~W}$ and $73 \mathrm{~W}$ weld-embrittled type specimens, the average fluence and standard deviation is approximately 1.9 and $0.3 \times 10^{19} \mathrm{n} / \mathrm{cm}^{2}(>1 \mathrm{MeV})$, respectively. A bar chart showing the distribution of fluence of the 18 specimens from the $72 \mathrm{~W}$ Series weldment is given in Fig. 4, (that for the specimens from the $73 \mathrm{~W}$ weldment is similar). The average irradiation temperature and the exposure values of each specimen are given later in this paper with the results of the crack-arrest testing. A detailed report on the dosimetry of the two capsules has been published [5] and another report on their operating history is in preparation.

The yield strength and Young's modulus of the test material are required in crack-arrest testing. The unirradiated and irradiated tensile strengths have been reproduced from Ref. [3] in Figs. 5 and 6 for welds $72 \mathrm{~W}$ and $73 \mathrm{~W}$ respectively. The average fluence of the tensile samples, approximately $1.6 \times$ $10^{19}$ neutrons $/ \mathrm{cm}^{2},(>1 \mathrm{MeV})$, is about $15 \%$ less than that for the crack-arrest specimens. This will not effect the values of the crack-arrest toughnesses $k_{a}$ but may have a small effect on the validity of each specimen as it is prescribed in ASTM E 1221-88. As mentioned elsewhere in this paper, the observations reached in this report are preliminary. Young's modulus is calculated from the following expression, [6]: $E=207.2-0.0571 \mathrm{~T}$, where $\mathrm{E}=$ Young's modulus in GPa, and $\mathrm{T}=$ temperature in ${ }^{\circ} \mathrm{C}$.

The RTMr values for both weldinents in the unirradiated and irradiated conditions are given in Table 3, (Refs. [3] and [4]). The initial RT THD values were determined in accordance with Subarticle NB-2330 of the ASME Boiler and Pressure Vessel Code, Section III, and are the same as the drop weight NDT 
Effects of Neutron Irrad. on KIa

- Nashville Faper

January $15,199112: 39$ pm Page 12

values. The "adjusted" $\mathrm{RT}_{\mathrm{NDT}}$ values were determined according to paragraph 10.2.2 of ASTM E 185-82 by adding the CVN $\Delta \mathrm{TT}_{41-\mathrm{J}}$ values to the initial $\mathrm{RT}_{\mathrm{NDT}}$ values. The CVN $\Delta \mathrm{TT}_{41 \mathrm{~J}}$ shifts have been determined from a relatively large number of specimens as shown in Fig. 7 (also from Refs. [3] and [4]). Approximately 84 and 56 unirradiated and irradiated CVN specimens were tested from eau of the $72 \mathrm{~W}$ and $73 \mathrm{~W}$ welds, respectively. The fluence of CVN-impact energy specimens from the $72 \mathrm{~W}$ and $73 \mathrm{~W}$ weldments is $1.51 \times 10^{19}$ neutrons $/ \mathrm{cm}^{2}$, while that for the crack-arrest specimens is approximately $1.9 \times 10^{19}$ neutrons $/ \mathrm{cm}^{2}$. In order to normalize the $\mathrm{KT} \mathrm{T}_{\mathrm{NDT}}$ shift, an average trend curve applicable to the behavinr of test reactor data and having a slope of 0.5 was used, [7]. It is of the form:

$$
\text { Normalized } \Delta \operatorname{TT}_{41-\mathrm{J}}=\left(\Delta \operatorname{TT}_{41-\mathrm{J}}\right)\left(\Phi^{\prime} / \Phi\right)^{0.5}
$$

where $\Phi^{\prime}$ and $\Phi$ are the average fluences for the crack-arrest and the CVN-impact specimens respectively, in neutrons $/ \mathrm{cm}^{2}(>1 \mathrm{MeV})$. Both shifts for each weldinent are given in Table 3. The normalized $R T_{\text {NDT }}$ values were used to shift the ASME $K_{\text {I a }}$ curves shown later in this paper.

Tables 4 and 5 give the results of testing the unirradiat- $d$ crack-arrest specimens of the $72 \mathrm{~W}$ and $73 \mathrm{~W}$ Series respectively, and Tables 6 and 7 give data for" the irradiated specimens of these two Series. The latter two tables also give the irradiation temperatures and the exposure values, (fluences for energies greater than $1 \mathrm{MeV}$ and greater than $0.1 \mathrm{MeV}$, as well as the displacements per atom - dpa). The crack-arrest toughnesses $k_{a}$ are plotted as a function of the test temperature for the $72 \mathrm{~W}$ and $73 \mathrm{~W}$ weldments in Figs. 8 and 9 respectively. In Tables 4 - 7, the results of the crack-arrest tests that were "invalid" relative to the requirements of ASTM E $1221-88$ are indicated by one or more 
Effects. of Neutron Irrad. on KIu

Nashville Paper

January 15, 1991 12:39pm Page 13

letters, a blank implying a valid result.

It should be mentioned that the irradiated $K_{a}$-values have not been normalized to a single average fluence to account for the variation of fluence from one specimen to another. Thus, the question arises as to whether the scatter in the $K_{a} \cdot$ values could be attributed to the variation in fluence between the specimens. An examinatio, of Tables 6 and 7 reveal that the fluence does not seem to be a contributing factor in the scatter, since the variation in fluence between specimens tested at the some temperature is relatively small. For example, if dat for the 4 specimens tested at $75^{\circ} \mathrm{C}$ from the $73 \mathrm{~W}$ weld are examined, the $\mathrm{K}_{\mathrm{a}}$ values range from 88 to $150 \mathrm{MPa} \sqrt{\mathrm{m}}$ with au average value of 119 $M \mathrm{~Pa} \sqrt{\mathrm{m}}$. Thus, the maximum and minimum values of $\mathrm{K}_{\mathrm{a}}$ at that temperature are approximately \pm 258 smaller or greater then the average value. The criresponding range of fluence for the specimens exhibiting the maximum and minimum $k_{a}$-value is less than $\pm 5 q$. Moreover, the scatter of the unirradiated $K_{a}$-values is approximately the same as that of the irradiated $\mathrm{K}_{\mathrm{a}}$-values. Nonetheless, statistical analysis of the data will be performed and normalization of the $\mathrm{K}_{\mathrm{a}}$ values to a single fluerze could then be considered.

One specimen in Table 7, A73W17, the crack failed to initiate in a cleavage mode, and exhibited tearing. It was retested at $30^{\circ} \mathrm{C}$, but the crack did not arrest, and the specimen broke. The $k_{a}$ value from specimen A73W37 (tested at $25^{\circ} \mathrm{C}$ ), is recognized as too low because the arrested crack length $a_{a}$ is 968 of the nominal specimen width $W$. The expression in ASTM E 1221-88 used to calculate $K_{a}$ is limited to $a_{a} / W \leq 0.85$. While ocier specimens may be slightly invalid and hence may or may not necessarily represent plane-strain behavior, the authors 
believe this specimen to be so far beyond the validity limits as to be clearly non-representative of plane-strain crack-arrest toughness of the weld. Hence its position is below the ASME $K_{1 a}$ curve in the figures given later in this paper is of no significance. In geroral, even though some of the other individual specimens may not strictly meet all of the ASTM validity criteria, the authors believe the data to be representative of the arrest toughness which would exist within a thick-walled RPV.

The task group responsible for the ASTM crack-arrest test procedure E 1221 recognized the need for the data to be under plain-strain conditions. Conservative validity criteria were selected, based on existing analytical and experimental results, [8] to assure that specimens which met those criteria would indeed be representative of plane-strain conditions. Even at that time, however, it was recognized that those criteria might be overly restrictive, but they were nonetheless chosen to be utilized until more evidence justifying their relaxation could be amassed. More data are now available; for example, Ref. [9] shows crack arrest test results, clearly violating the size criteria of ASTM E 1221-88, which still accurately predict the arrest behavior of a thickwalled pressure vessel under simulated pressurized-thermal loading. Based on these and other considerations, the ASTM task group will be asked to reconsider the relasation of the validity criteria.

The crack-arrest toughness $K_{a}$ of the $72 \mathrm{~W}$ and $73 \mathrm{~W}$ weldments presented in Figs. 8 and 9 also show the unirradiated and irradiated ASME $K_{I a}$ curves for each weldment indexed to their respective $\mathrm{RT}_{\text {HDT }}$ values. Lower-bound curves to the test results have also been plotted as dotted curves. The doted curves are the 
ASME curves shifted to the left towards a lower temperature (or downwards in temperature) until the first data point is encountered. The anount of the shift for each material is given in Figures 8 and 9 as a temperature difference in Kelvin (K) between the solid and dotted curves. The downward shifts in temperature for weld $72 \mathrm{~W}$ are 28 and $36 \mathrm{~K}$ for the $\mathrm{j}$ rradiated and unirradiated data respectively, and the corresponding temperature shifts for weld $73 \mathrm{~W}$ are 39 and $28 \mathrm{~K}$ respectively. Thus, in case of $72 \mathrm{~W}$, the shift downward in temperature from the normalized curve for the irradiated specimens is smaller than for unirradiated ones by $8 \mathrm{~K}$. For the $73 \mathrm{~W}$ specimens, however, the opposite is obtained; the shift for the irradiated condition is $11 \mathrm{~K}$ greater than that for the unirradiated. With all the uncertainties involved, the differences between the downward shifts are not deemed to be significant. Thus, the preliminary observation is that the shift in $\mathrm{K}_{\mathrm{a}}$ due to irradiation is about the same as the shift of the CVN impact energy at the $41-\mathrm{J}$ energy level as may be judged by the dotted curves in Figs. 8 and 9.

The ASME curve when shifted by the normalized CVN $\triangle \mathrm{TT}_{41-\mathrm{J}}$ is a conservative estimate of the irradiated crack-arrest toughness of the $72 \mathrm{~W}$ and $73 \mathrm{~W}$ weldments in the transition region to approximately $40 \mathrm{~K}$ above the $\mathrm{RT}_{\mathrm{NDT}}$. At temperatures below the $\mathrm{RT}_{\text {HDT }}$, there is a smaller: $\mathrm{K}_{\mathrm{I}}$ margin between the lower-bound curves and the ASME $\mathrm{K}_{\mathrm{Ia}}$ curves. For example, the lower-bound values are approx. 70,35 , and 10 o higher than the $A S M E K_{I a}$ values at temperatures with respect to $R T_{N D T}$ of +50 , 0 , and $-50 \mathrm{~K}$.

The shape of the lower-bound curves for the data obtained in Phase 1 of the 
6th Irradiation Series does not seem to have been altered by irradiation. Moreover, the lower-bound crack-arrest curves have about the same shape as that of the ASME $K_{I}$ curve. The CVN-impact energy curve for the $72 \mathrm{~W}$ weld, and more so for the $73 \mathrm{~W}$ weld, changed shape when irradiated to a fluence level of $1.51 \times$ $10^{19}$ neutrons $/ \mathrm{cm}^{2}(>1 \mathrm{MeV}),($ see Ref. [3] and Fig. 7). There are many empirical correlations between the CVN-impact energy and fracture toughness of unirradiateci ferritic steels [10]. Assuming that such a relationship also exists for irradiated ferritic steels, if the irradiated CVN curve changes shape, then the irradiated fracture toughness curve may also change shape correspondingly. One of the objectives of the 5 th and 6 th Irradiation Series research programs is to investigate whether irradiation induces such a shape change in the toughness curves. Indeed, such a change has been observed in the lower-bound curve to the irradiated initiation toughness $K_{J c}$ data for the $73 \mathrm{~W}$ weldment; similarly, a change in shape of the CVN impact energy curve was observed [3]. Although no such change in shape has been observed in che $\mathrm{K}_{\mathrm{a}}$ data obtained in tests to approx. $40 \mathrm{~K}$ above $\mathrm{RT}_{\mathrm{NDT}}$, further tests at higher temperatures are needed to ascertain whether a similar change in shape occurs in the arrest toughness curve.

Successful cleavage crack initiation occurred in 35 of the 36 specimens tested. Such a success rate is unusual even for testing unirradiated specimens. Moreover, successful unstable crack initiation occurred in weld-embrittled type specimens at test temperatures $40 \mathrm{~K}$ above NDT. A test temperature of approximately $20 \mathrm{~K}$ above the NDT is generally considered to be the upper limit for a successful unstable crack to initiate in unirradiated weld-embrittled type crack-arrest specimens for the steels and specimen thicknesses used here. It is likely that the radiation-induced increases in strength of the test material and 
Effects of Neutron Irrad. on KIa

Nashvillo Paper

January 15, $1991 \quad 12: 39 \mathrm{pm}$ Page 17

the r.rittle weld crack starter material allows for a higher crack driving force enabling testing at higher temperatures.

Comparison with Other Data

Almost all the published data on the effect of irradiation on crack-arrest toughness is contained in the Electric Power Research Institute (EPRI) report by Mager and Marschall [2]. Four steels were tested in the EPRI project: two welds and two plate materials. Both the plates and the welds included a low-copper as well as a high-copper steel. Six to 12 specimens were tested from each of the four materials for a total of 36 and 34 specimens in the unirradiated and irradiated condition, respectively. The results of the irradiated crack-arrest toughness were compared to the unirradiated data by shifting the irradiated data downwards in temperature to achieve an approximate data coincidence. The EPRI downward shift is approximately comparable to the lower-bound one used in the present paper (obtained by shifting the ASME $\mathrm{K}_{\mathrm{I} a}$ curve downwards in temperature until the first data point is encountered). The EPRI shift in $K_{I a}$ due to irradiation for high-copper materials is less than the $\Delta \mathrm{TT}_{41-\mathrm{J}}$, whereas for the low-copper materials, the shift in $\mathrm{K}_{\mathrm{Ia}}$ is slightly greater or equal to $\Delta \mathrm{TT}_{41-\mathrm{J}}$, (in the EPRI program, the CVN shifts were also evaluated in several other ways). In this study a similar trend is obtained, although the range of copper contents is quite different. In the EPRI program, the copper contents ranged from approximately 0.03 to 0.23 s by weight. In the present study, the copper contents for the two materials are 0.23 and $0.31 z$ and the normalized $\Delta \mathrm{TT}_{41-\mathrm{J}}$ are 80 and $93 \mathrm{~K}$ for the $72 \mathrm{~W}$ and $73 \mathrm{~W}$ welds, respectively, while the shifts of the lower-bound $\mathrm{K}_{\mathrm{a}}$ curves were 88 and $82 \mathrm{~K}$ for the $72 \mathrm{~W}$ and $73 \mathrm{~W}$ welds, respectively. This study also increased the maximum values of irradiated crack-arrest toughness 
Effects of Neutron Irrad. on KIa

obtained when compared to those of the EPRI program from approximately 130 to $185 \mathrm{MPa} \cdot / \mathrm{m}$. Irradiated crack-arrest toughness data for both welds in this study were also obtained at higher temperatures with respect to the normalized $\mathrm{RT}_{\mathrm{NDT}}$ (up to $40 \mathrm{~K}$ above the $\mathrm{RT}_{\mathrm{NDT}}$ ) than the EPRI data for the high-copper weld (EPRI data were obtained up to approximately the adjusted $\mathrm{RT}_{\mathrm{NDT}}$ ).

\section{SUMMARY}

Crack-arrest testing of high copper submerged-arc welds has been performed on unirradiated and irradiated weld embrittled type specimens 25 and 33 -mm thick. Most of the crack-arrest test results are either valid or only marginally invalid according to ASTM E 1221-88. The 34 data points obtained by testing the irradiated crack-arrest specimens have approximately doubled the known data base of irradiated crack-arrest toughness and extended it to higher levels of crackarrest toughness and temperature relative to $\mathrm{RT}_{\mathrm{NDT}}$. Preliminary observations are:

1. Values of irradiated crack-arrest toughness $K_{a}$ were obtained at temperatures $40 \mathrm{~K}$ above the irradiated $\mathrm{RT}_{\text {NDT }}$ of the welds. This is significant because a temperature of 20 , above the $\mathrm{RT}_{\text {NDT }}$ is generally considered to be the limit for obtaining useful results with the unirradiated weld-embrittled type of crack-arrest specimen.

2. The shifts of the lower-bound $\mathrm{K}_{\mathrm{a}}$ curves for the $72 \mathrm{~W}$ and $73 \mathrm{~W}$ welds are approximately the same as the corresponding $41-\mathrm{J}$ CVN-impact energy level 
Effects of Neutron Irrad, on KIa

Nashville Paper

January 16, 1991 10:09am Page 19

shilts.

3. The ASME $K_{I a}$ curve, when shifted by $\Delta \mathrm{TT}_{41-\mathrm{J}}$ is a conservative estimate of the irradiated crack-arrest toughness for welds $72 \mathrm{~W}$ and $73 \mathrm{~W}$ in the transition region about $40 \mathrm{~K}$ above the $\mathrm{RT}_{\mathrm{NDT}}$. At temperatures below the $\mathrm{RT}_{\mathrm{NDT}}$, there seems to be a smaller margin of toughness between the lowerbound curves and the ASME $\mathrm{K}_{\mathrm{Ia}}$ curves.

4. The shrpe of the lower-bound curves compared to those of the ASME $\mathrm{K}_{\mathrm{Ia}}$-curve did not seem to have been altered by irradiation for the test temperature range covered by the tests.

\section{ACKNOWLEDGMENTS}

The following individuals not only contributed to the various tasks mentioned but also made many useful suggestions. The authors acknowledge Ken $R$. Thoms and Bill H. Montgomery for capsule design and operation, respectively and Frank B. Kam for dosimetry. The authors also wish to acknowledge Eric $\mathrm{T}$. Manneschmidt, $J$. Hoyt Mason, Jr, and John J. Henry, Jr. for testing the irradiated specimens; Thomas D. Owings for specimen fabrication, testing of the unirradiated specimens and for test fixture assembly and shakedown; Ronald L. Swain and David Thomas for assistance with equipment; Lloyd Turner for coordination of activities in the hot-cell; Bill $\mathrm{H}$. Grubb for making modifications to the test fixture during shakedown and for the design and manufacture of a jig for transporting irradiated specimens; John G. Merkle and David J. Alexander for their helpful reviews. The authors would like to 
Effects of Neutron Irrad. on KIa

Nashville Paper

January 16, 1991 9:59am Page 20

acknowledge the support and encouragement of Milton Vagins during the initial phases of this project.

The authors also appreciate the financial support and encouragement of the Nuclear Regulatory Commission (NRC) and Alfred Taboada, the current NRC technical monitor.

\section{$\underline{\text { References }}$}

1. C. W. Marschall and A. R. Rosenfield, "Crack-Arrest Tests of Irradiated High-Copper ASTM A508 Submerged-Arc Weld Metal," International Conference on Fracture, Advances in Fracture Research, Vol. 5, pp. 2467-2475, April 1981.

2. T. R. Mager and C. W. Marschall, "Development of a Crack Arrest Toughness Data Bank for Irradiated Reactor Pressure Vessel Materials, " EPRI NP-3616, Electric Power Research Institute, July 1984.

3. R. K. Nanstad, D. E. McCabe, Blaine H. Menke, S. K., Iskander, and F. M. Haggag, "Effects of Irradiation on $K_{\text {Tc }}$ curves for High-Copper Welds," Effects of Radiation on Materials, 14th International Symposium, (Volume II), ASTM STP 1046, N. H. Packan, R. E. Stoller, and A. S. Kumar, Eds., American Society for Testing and Materials, Philadelphia, 1990, pp. 214 233.

4. R. K. Nanstad, F. M. Haggag, and S. K. Iskander, "Radiation-Induced Temperature Shift of the ASME $K_{I c}$ Curve," pp. 143-148, Transactions of the 
Effects of Neutron Irrad. on KIa

January 16, 1991 9:59am Page 21

10th International Conference on Structural Mechanics in Reactor Technology (SMiRT), Voi. S, Editor Asadour H. Hadgjian, Anaheim, California, August 1989.

5. L. F. Miller, C. A. Baldwin, F. W. Stallmann, and F. B. K. Kam, "Neutron Exposure Parameters for the Metallurgical Test Specimens in the Sixth Heavy-Section Steel Irradiation Series," NUREG/CR-5409 (ORNL/TM-11267), Martin Marietta Energy Systems, Irıc., Oak Ridge Natl. Lab., May 1990.

б. W. L. Server, J. W. Sheckherd, and R. A. Wullaert, "Fracture Toughness Data for Ferritic Nuclear Pressure Vessel Materials," EPRI NP-119, Electric Power Research Institute, April 1976.

7. G. R. Odette and G. E. Lucas, "Irradiation Embrittlement of Reactor Pressure Vessel Steels: Mechanisms, Models, and Data Correlations," Radiation Embrittlement of Nuclear Pressure Vessel Steels: An International Review (Second Volume), ASTM STP 909, L. E. Steel, Ed., American Society for Testing and Materials, Philadelphia, 1986, pp. 206 241.

8. D. B. Barker, R. Chona, W. L. Fourney, and G. R. Irwin, "A Repcrt on the Round Robin Program Conducted ío Evaluate the Proposed ASTM Standard Test Method for Determining the Plane-Strain Crack-Arrest Fracture Toughness, Ka, of Ferritic Materials," NUREG/CR-4996 (ORNL/Sub/79-7778/4), Martin Marietta Energy Systens, Inc, , Oak Ridge Natl. Lab., January 1988. 
Effects of Neutron Irrad, on KIa

Nashville Paper

January 16, 1991 9:59am Page 22

9. R. H. Bryan et a1., "Pressurized-Thermal-Shock Test of 6-in.-Thick Pressure Vesse1s. PTSE-2: Investigation of Low Tearing Resistance and Warm Prestressing,", NUREG/CR-4888 (ORNL-6377), Martin Marietta Energy Systems, Inc., Oak Ridge Nat1. Lab., December 1987.

10. Stanley T. Rolfe and John M. Barsom, "Fracture and Fatigue Control in Structures", Chapter 6, Prentice-Hall, Inc., New Jersey, 1977. 
Effects of Noutron Irrad. on KIa

Nashville Paper

January 14, $19914: 33 \mathrm{pm}$ Page 1

\section{List of Tables.}

Table

Number

1. Chemical composition of the two submerged-arc welds in the Fifth and Sixth Irradiation Series.

2. Irradiated crack-arrest specimen complement for each of the $72 \mathrm{~W}$ and $73 \mathrm{~W}$ weldments.

3. Initial, adjusted, and normalized reference temperatures (RT $\mathrm{T}_{\mathrm{NT}}$ ) for the $72 \mathrm{~W}$ and $73 \mathrm{~W}$ weldments

4. Unirradiated crack arrest toughness data obtained from testing weldment $72 \mathrm{~W}\left(\mathrm{RT}_{\mathrm{NDT}}=-23^{\circ} \mathrm{C}\right)$.

5. Unirradiated crack arrest toughness data obtained from testing weldment $73 \mathrm{~W}\left(\mathrm{RT}_{\mathrm{NDT}}=-34^{\circ} \mathrm{C}\right)$.

6. Irradiated crack arrest toughness data for the weld-embrittled type spacimens from weldment $72 \mathrm{~W}\left(\mathrm{RT}_{\mathrm{NDT}}=57^{\circ} \mathrm{C}\right)$. The average fluence and irradiation temperature were $1.88 \times 10^{19}$ neutrons $/ \mathrm{cm}^{2}$ and $287^{\circ} \mathrm{C}$ respectively.

7. Irradiated crack arrest toughness data for the weld-embrittled type specimens from weldment $73 \mathrm{~W}\left(\mathrm{RT}_{\text {MDT }}=59^{\circ} \mathrm{C}\right)$. The average fluence and irradiation temperature were $1.93 \times 10^{19}$ neutrons $/ \mathrm{cm}^{2}$ and $287^{\circ} \mathrm{C}$ respectively. 
Table 1. Chemical composition of the two submerged-arc welds in the HSSI Fifth and Sixth Irradiation Series ${ }^{1}$

\begin{tabular}{lccccccccccccc}
\hline & \multicolumn{1}{c}{ Material } & \multicolumn{1}{c}{} & $\mathrm{C}$ & $\mathrm{Mn}$ & $\mathrm{P}$ & $\mathrm{S}$ & $\mathrm{Si}$ & $\mathrm{Cr}$ & $\mathrm{Ni}$ & $\mathrm{Mo}$ & $\mathrm{Cu}$ & $\mathrm{V}$ \\
\hline $72 \mathrm{~W}$ & 0.093 & 1.60 & 0.006 & 0.006 & 0.44 & 0.27 & 0.60 & 0.58 & 0.23 & 0.003 \\
$73 \mathrm{~W}$ & 0.098 & 1.56 & 0.005 & 0.005 & 0.45 & 0.25 & 0.60 & 0.58 & 0.31 & 0.003 \\
\hline
\end{tabular}

1

Ref: R. K. Nanstad et al., "Effects of Irradiation on $\mathrm{K}_{\mathrm{Ic}}$ curves for High-Copper Welds," Effects of Radiation on Materials, 14th International Symposium, ASTM STP 1046, Vol. II, N. H. Packan, R. E. Stoller, and A. S. Kumar, Eds., American Society for Testing and Materials, Philadelphia, 1990, pp. 214-233. 
Table 2. Irradiated crack-arrest specimen complement for each

of the $72 \mathrm{~W}$ and $73 \mathrm{~W}$ weldments.

\begin{tabular}{lll}
\hline Specimen type & $\begin{array}{c}\text { Dimensions } \\
(\mathrm{mm})\end{array}$ & $\begin{array}{c}\text { Quantity } \\
\text { per weld }\end{array}$ \\
\hline Weld-embrittled & $25 \times 76 \times 76$ & 8 \\
Weld-embrittled & $25 \times 152 \times 152$ & 7 \\
Weld-embrittled & $33 \times 152 \times 152$ & 3 \\
Duplex & $33 \times 152 \times 152$ & 12 \\
\hline
\end{tabular}




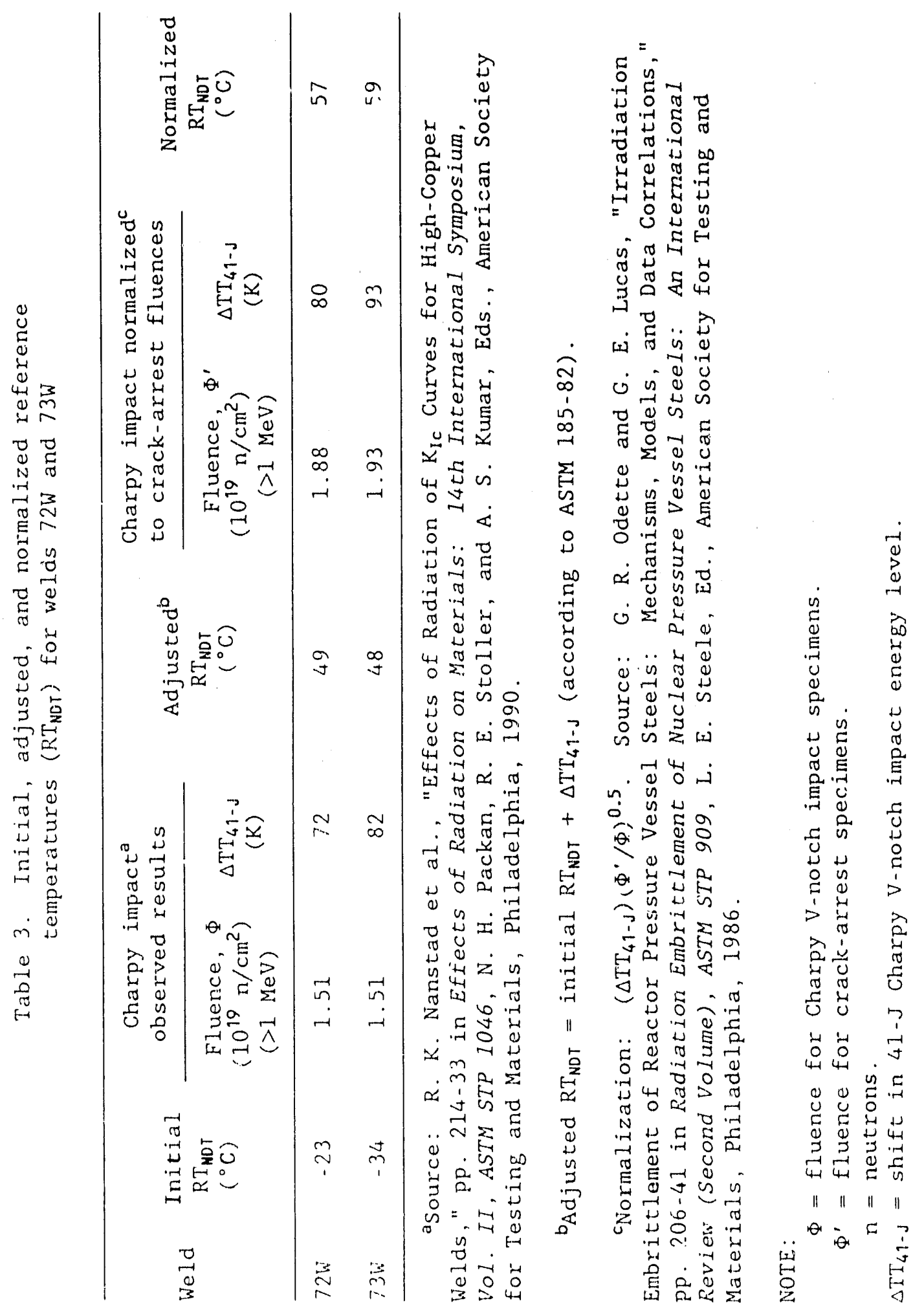


Table 4. Unirradiated crack arrest toughness data obtained from testing weldment $72 \mathrm{~W}\left(\mathrm{RT}_{\mathrm{NDT}}=-23^{\circ} \mathrm{C}\right)$.

\begin{tabular}{cccc}
$\begin{array}{c}\text { Specimen } \\
\text { ID }\end{array}$ & $\begin{array}{c}\text { Test } \\
\text { Temperature } \\
\left({ }^{\circ} \mathrm{C}\right)\end{array}$ & $\mathrm{K}_{\mathrm{a}}$ & Validity \\
& $\mathrm{MPa} \cdot \sqrt{\mathrm{m}}$ \\
\hline
\end{tabular}

Weld-embrittled $25 \times 76 \times 76 \mathrm{~mm}$ specimens

$\begin{array}{lrrr}\text { A72W37 } & -61 & 66 & \\ \text { A72W35 } & -60 & 53 & \\ \text { A72W38 } & -59 & 57 & \\ \text { A72W36 } & -47 & 71 & \\ \text { A72W34 } & -45 & 73 & \\ \text { A72W24 } & -30 & 61 & \\ \text { A72W28 } & -30 & 60 & \\ \text { A72W25 } & -30 & 79 & B \\ \text { A72W31 } & -15 & 108 & B, E\end{array}$

Weld-embrittled $25 \times 152 \times 152 \mathrm{~mm}$ specimens

$\begin{array}{llrl}\text { A72W44 } & -60 & 76 & \\ \text { A72W39 } & -60 & 45 & \text { A } \\ \text { A72W20 } & -47 & 67 & \\ \text { A72W41 } & -45 & 74 & \\ \text { A72W46 } & -45 & 92 & \\ \text { A72W43 } & -32 & 92 & \\ \text { A72W08 } & -30 & 104 & \\ \text { A72W05 } & -30 & 107 & \\ \text { A72W48 } & -30 & 98 & \\ \text { A72W01 } & -16 & 97 & \text { C } \\ \text { A72W03 } & -14 & 128 & \end{array}$

Weld-embrittled $33 \times 152 \times 152 \mathrm{~mm}$ specimens

$\begin{array}{rrr}\text { A72W45 } & -45 & 76 \\ \text { A72W47 } & -30 & 91 \\ \text { A72W07 } & -15 & 103 \\ \text { A72W04 } & -15 & 94 \\ \text { A72W19 } & -15 & 94 \\ \text { A72W02 } & 0 & 93 \\ \text { A72W12 } & 0 & 114 \\ \text { A72W40 } & 0 & 114\end{array}$

A

C 
Duplex $33 \times 152 \times 152 \mathrm{~mm}$ specimens

$\begin{array}{lrrr}\text { A72W71 } & -14 & 91 & \\ \text { A72W66 } & -2 & 103 & \\ \text { A72W63 } & -1 & 125 & \\ \text { A72W64 } & 1 & 108 & \\ \text { A72W65 } & 4 & 125 & \\ \text { A72W68 } & 5 & 115 & \text { C, D } \\ \text { A72W73 } & 5 & 142 & \text { B, C } \\ \text { A72W62 } & 10 & 136 & \text { C, D } \\ \therefore 72 W 57 & 21 & 146 & \end{array}$

Weld-embrittled $51 \times 203 \times 203 \mathrm{~mm}$ specimens

$\begin{array}{rrr}\text { A72W83 } & -30 & 85 \\ \text { A72W85 } & -15 & 95 \\ \text { A72W84 } & 0 & 107\end{array}$

Tre or more letters for a specimen indicate that the test results did not meet one of the minimum lengths of the ASTM E 1?21-88 validity criteria. The letters correspond to the ores in Table 2 of ASTM E 1221-88 whicin can be paraphrased as:

$A, B$ unbroken ligament too siort

C specimen too thin

$D, E$ insufficient crack-jump length 
Table 5. Unirradiated crack arrest toughness data obtained from testing weldment $73 \mathrm{~W}\left(\mathrm{RT}_{\mathrm{NDT}}=-34^{\circ} \mathrm{C}\right)$.

\begin{tabular}{cccc}
$\begin{array}{c}\text { Specimen } \\
\text { ID }\end{array}$ & $\begin{array}{c}\text { Test } \\
\text { Temperature } \\
\left({ }^{\circ} \mathrm{C}\right)\end{array}$ & $\mathrm{K}_{\mathrm{a}}$ & Validity ${ }^{1}$ \\
\hline
\end{tabular}

Weld-embrittled $25 \times 76 \times 76 \mathrm{~mm}$ specimens

$\begin{array}{llll}\text { A73W38 } & -62 & 50 & \text { A } \\ \text { A73W42 } & -60 & 58 & \\ \text { A73W32 } & -59 & 56 & \text { A } \\ \text { A73W36 } & -59 & 72 & \\ \text { A73W01 } & -45 & 52 & \\ \text { A73W02 } & -45 & 75 & \text { A, B } \\ \text { A73W03 } & -45 & 64 & \text { B } \\ \text { A73W06 } & -35 & 83 & \\ \text { A73W04 } & -30 & 67 & \text { A, B } \\ \text { A73W05 } & -30 & 70 & \end{array}$

Weld-embrittled $25 \times 1.52 \times 152 \mathrm{~mm}$ specimens

$\begin{array}{llrl}\text { A73W28 } & -61 & 69 & \\ \text { A73W43 } & -45 & 73 & \\ \text { A73W47 } & -45 & 85 & \\ \text { A73W30 } & -44 & 71 & \\ \text { A73W11 } & -32 & 85 & \\ \text { A73W48 } & -31 & 75 & \\ \text { A73W50 } & -30 & 80 & \\ \text { A73W16 } & -29 & 89 & \\ \text { A73W52 } & -29 & 77 & \text { C , C } \\ \text { A73W20 } & -16 & 126 & \\ \text { A73W25 } & -15 & 141 & \end{array}$

Weld-embrittled $33 \times 152 \times 152 \mathrm{~mm}$ specimens

$\begin{array}{lrrr}\text { A73W29 } & -30 & 100 & \\ \text { A73W10 } & -16 & 77 & \text { A } \\ \text { A73W22 } & -16 & 110 & \\ \text { A73W46 } & -15 & 124 & \\ \text { A73W44 } & -15 & 123 & \\ \text { A73W49 } & -15 & 117 & \\ \text { A73W24 } & -13 & 89 & \text { A, B } \\ \text { A73W27 } & -12 & 111 & \end{array}$


Duplex $33 \times 152 \times 152 \mathrm{~mm}$ specimens

$\begin{array}{lrlc}\text { A73W86 } & -5 & 101 & \\ \text { A73W07 } & 5 & 129 & \text { B } \\ \text { A73W08 } & 5 & 119 & \\ \text { A73W09 } & 5 & 112 & \\ \text { A73W85 } & 5 & 137 & \text { C, D } \\ \text { A73W87 } & 5 & 113 & \\ \text { A73W88 } & 15 & 132 & \end{array}$

Duplex $51 \times 203 \times 203 \mathrm{~mm}$ specimen

A73W75 $\quad 5 \quad 107$

${ }^{1}$ One or more letters for a specimen indjcate that the test results did not meet one of the minimum lengths of the ASTM E 1221-88 validity criteria. The letters correspond to the ones in Table 2 of ASTM E 1221-88 which can be paraphrased as:

$A, B$ unbroken ligament too short

$C$ specimen too thin

$D, E$ insufficient crack-jump length 


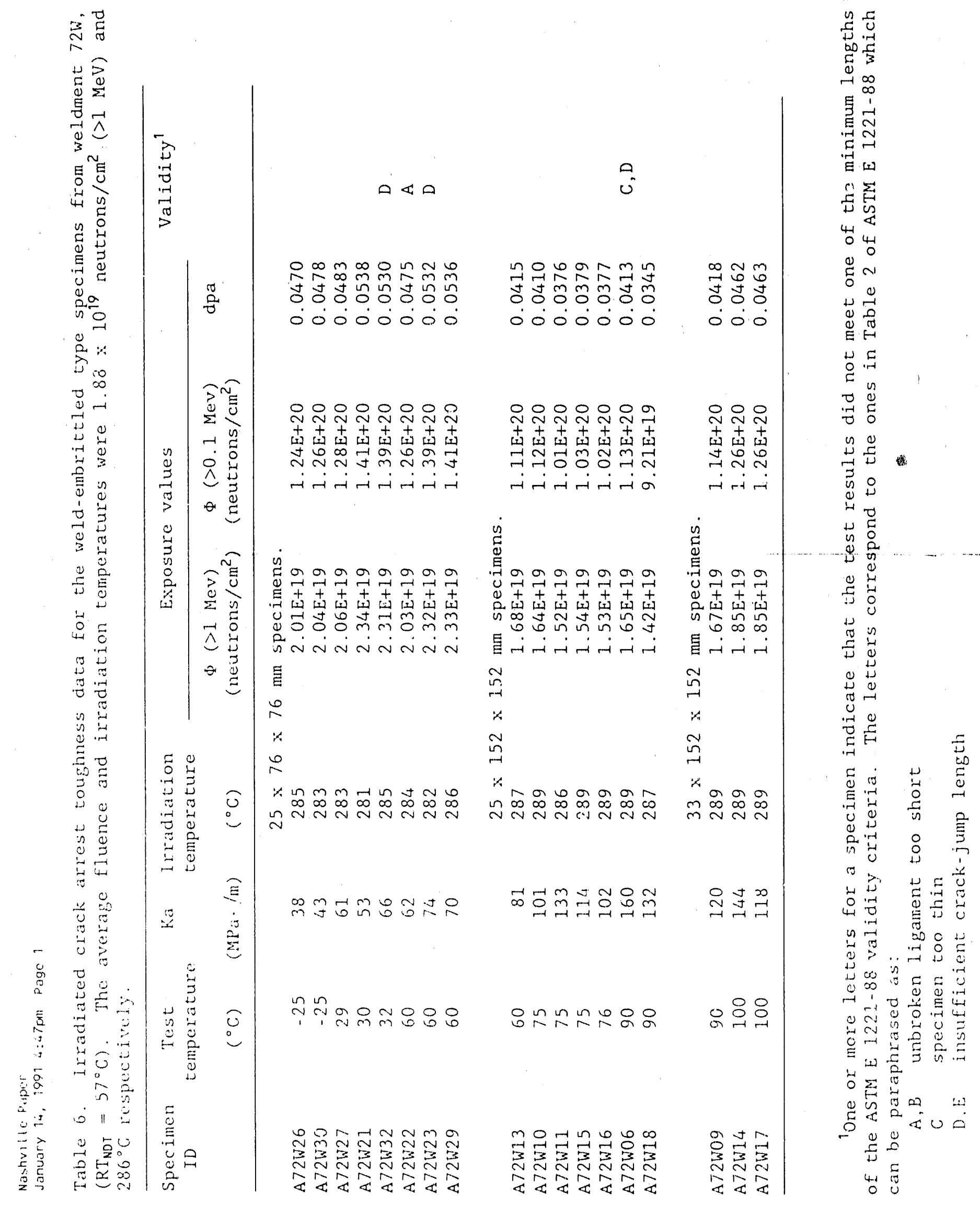




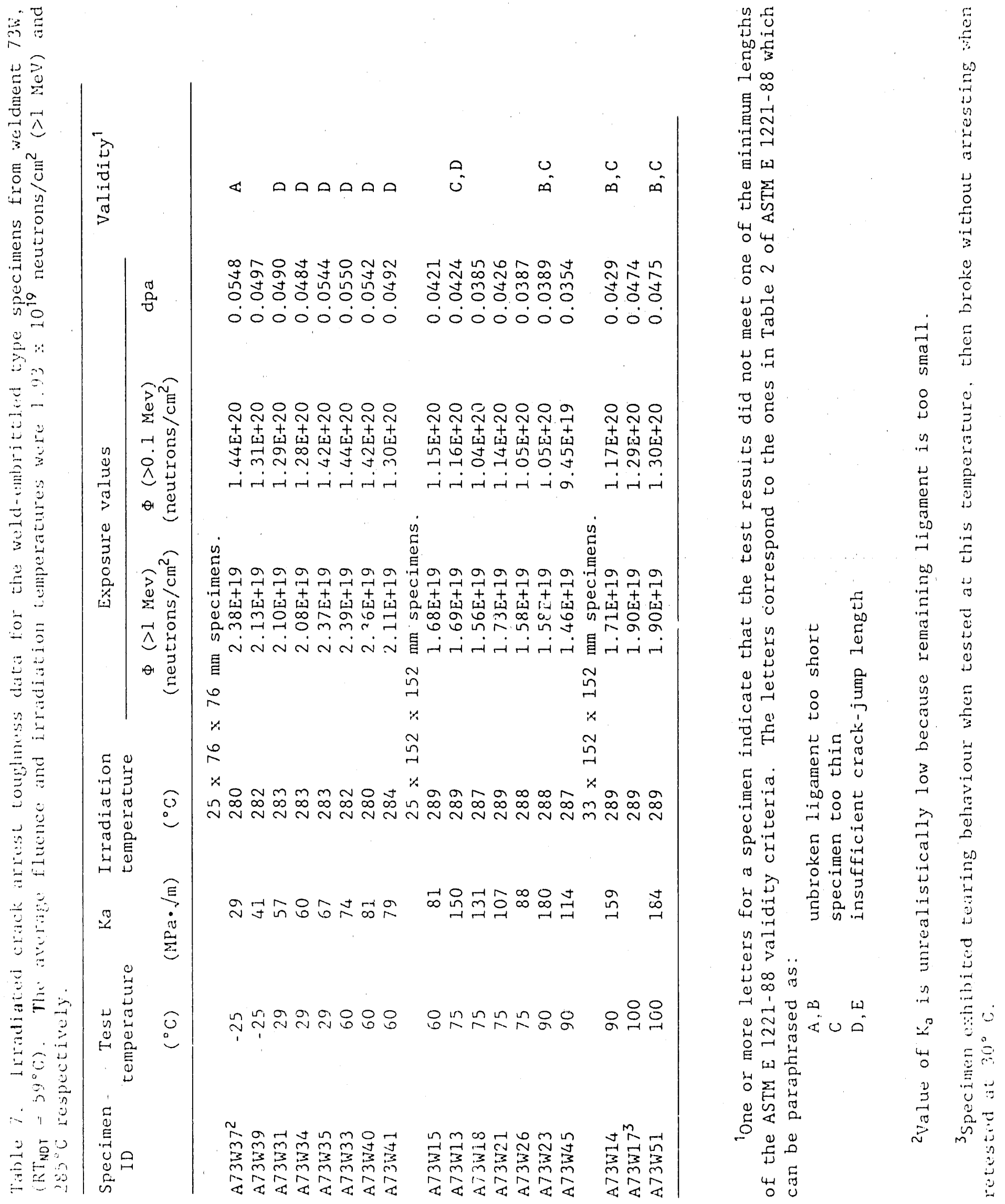


1. Cross section of typical submerged-arc weld used in the $72 \mathrm{~W}$ and $73 \mathrm{~W}$ welds of the Fifth and Sixth Irradiation Series. The welds were made with specially produced wire. (with copper added to the melt) and fabricated in 220 -mm-thick plate.

2. Schematic drawing of equipment used to perform crack-arrest testing of irradiated specimens before it was set up in the hot-cell 500-kN testing machine.

3. Photograph taken through a Kollmorgen periscope of the fracture surfaces of two typical crack arrest specimens after heat-tinting and splitting them open. The 2 or $3 \mathrm{~mm}$ darker, transverse strips near the initial crack front are the brittle crack starter weld beads.

4. Distribution of fluence in the 18 irradiated weld-embrittled type crack specimens tested from the $72 \mathrm{~W}$ weldment.

5. Yield and ultimate strengths vs test temperature for weld $72 \mathrm{~W}$ (a) unirradiated and (b) irradiated at a nomial temperature of $288^{\circ} \mathrm{C}$ to 1.57 $\times 10^{19}$ neutrons $/ \mathrm{cm}^{2}$ ( $\left.>1 \mathrm{MeV}\right)$.

6. Yield and ultimate strengths vs test temperature for weld $73 \mathrm{~W}$ (a) unirradiated and (b) i.rradiated at a nominal temperature of $288^{\circ} \mathrm{C}$ to 1.56 $x 10^{19}$ neutrons $/ \mathrm{cm}^{2}$ ( $\left.>1 \mathrm{MeV}\right)$.

7. CVN-impact energy vs test temperature for welds $72 \mathrm{~W}$ and $73 \mathrm{~W}$ (a) unirradiated and (b) irradiated at a nominal temperature of $288^{\circ} \mathrm{C}$ to 1.51 x $10^{19}$ neutrons $/ \mathrm{cm}^{2}(>1 \mathrm{MeV})$.

8. Unirradiated and irradiated crack arrest toughness $k_{a} v s$ test temperature for the $72 \mathrm{~W}$ weldment. The dotted curves are lower bounds to the data obtained by shifting the ASME curves to a lower temporatire by the amounts shown.

9. Unirradiated and irradiated crack arrest toughness $K_{a}$ vs test temperature for the $73 \mathrm{~W}$ weldment. The dotted curves are lower bounds to the data obtained by shifting the ASME curves to a lower temperature by the amounts shown. 


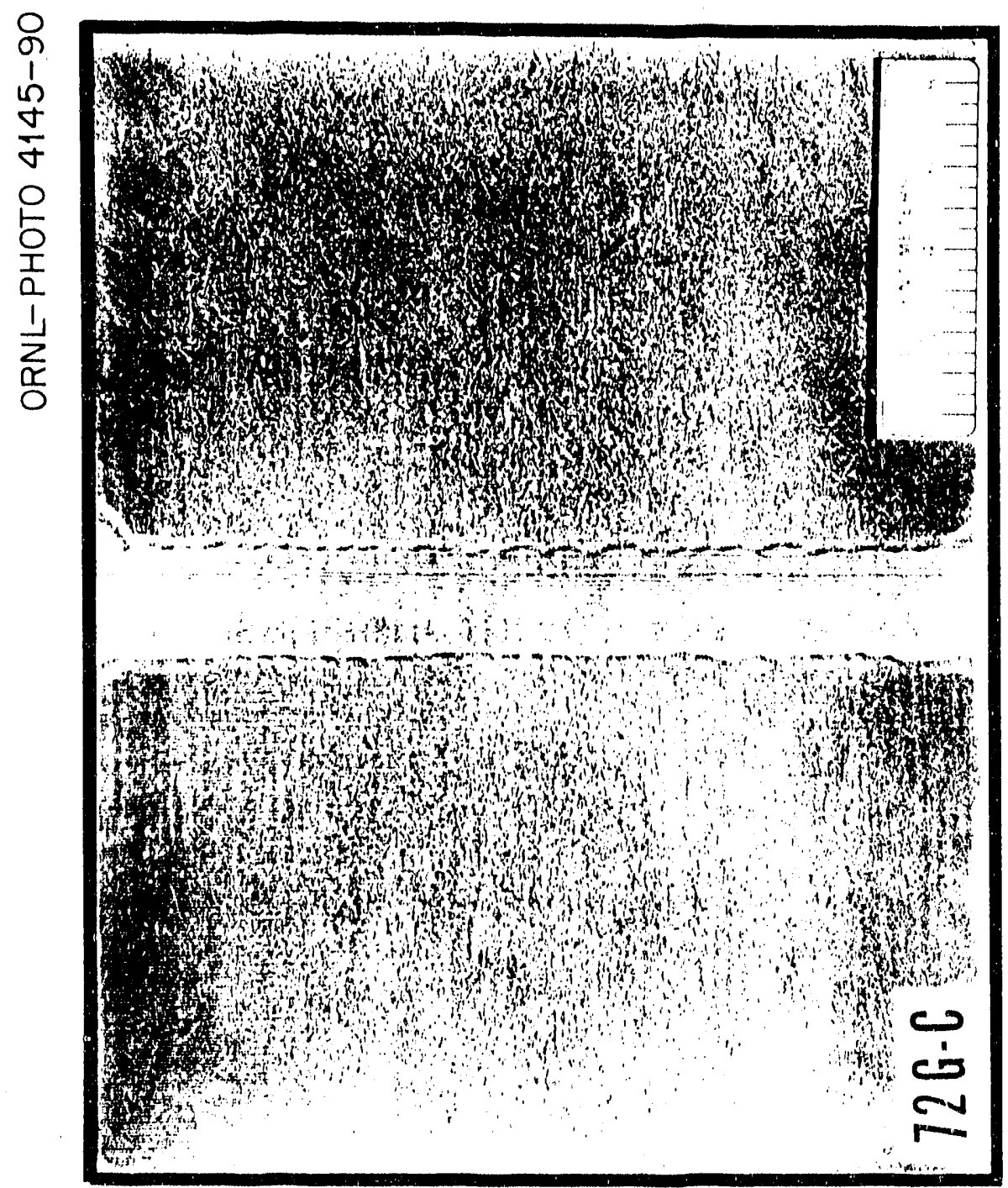




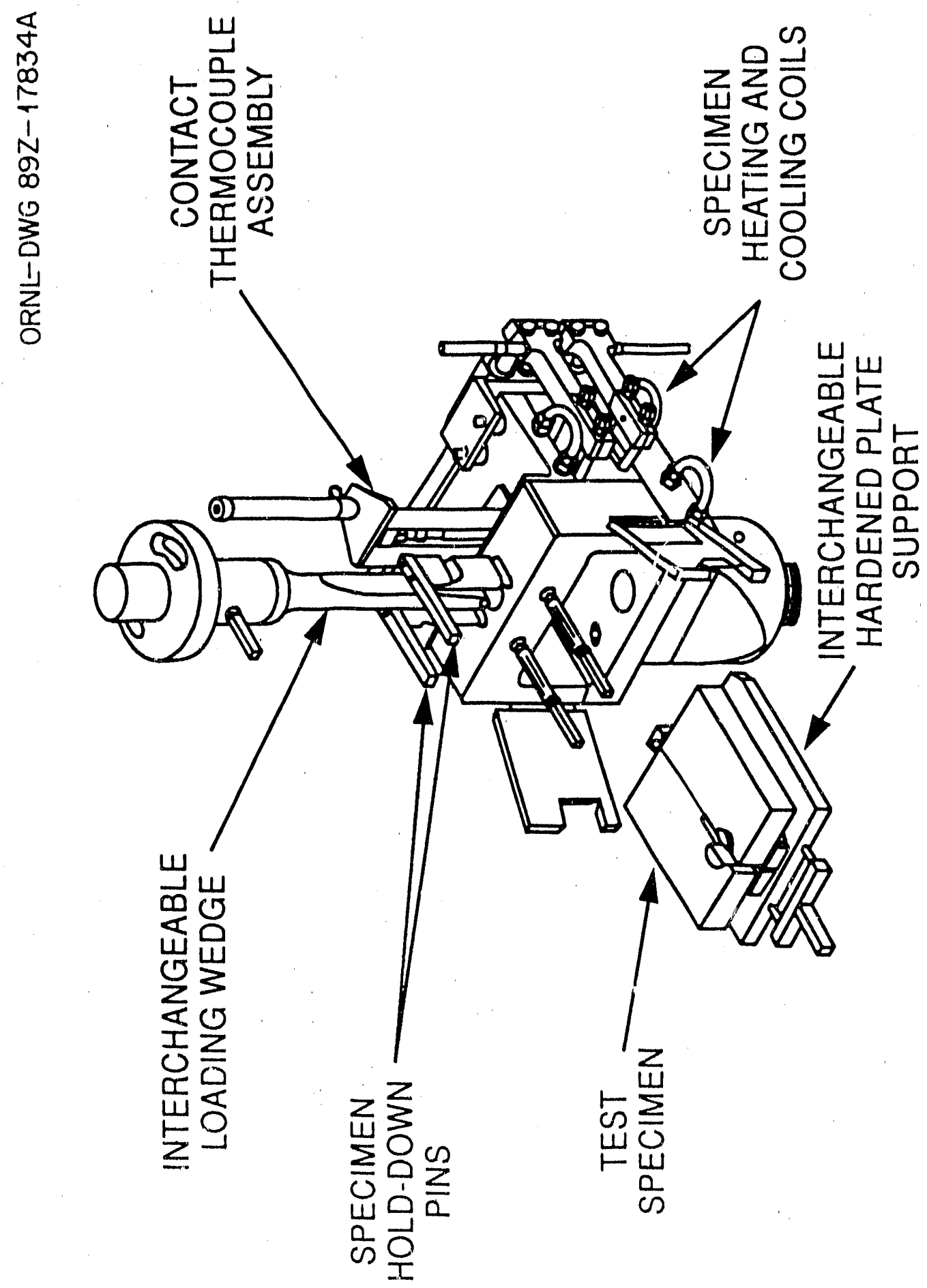




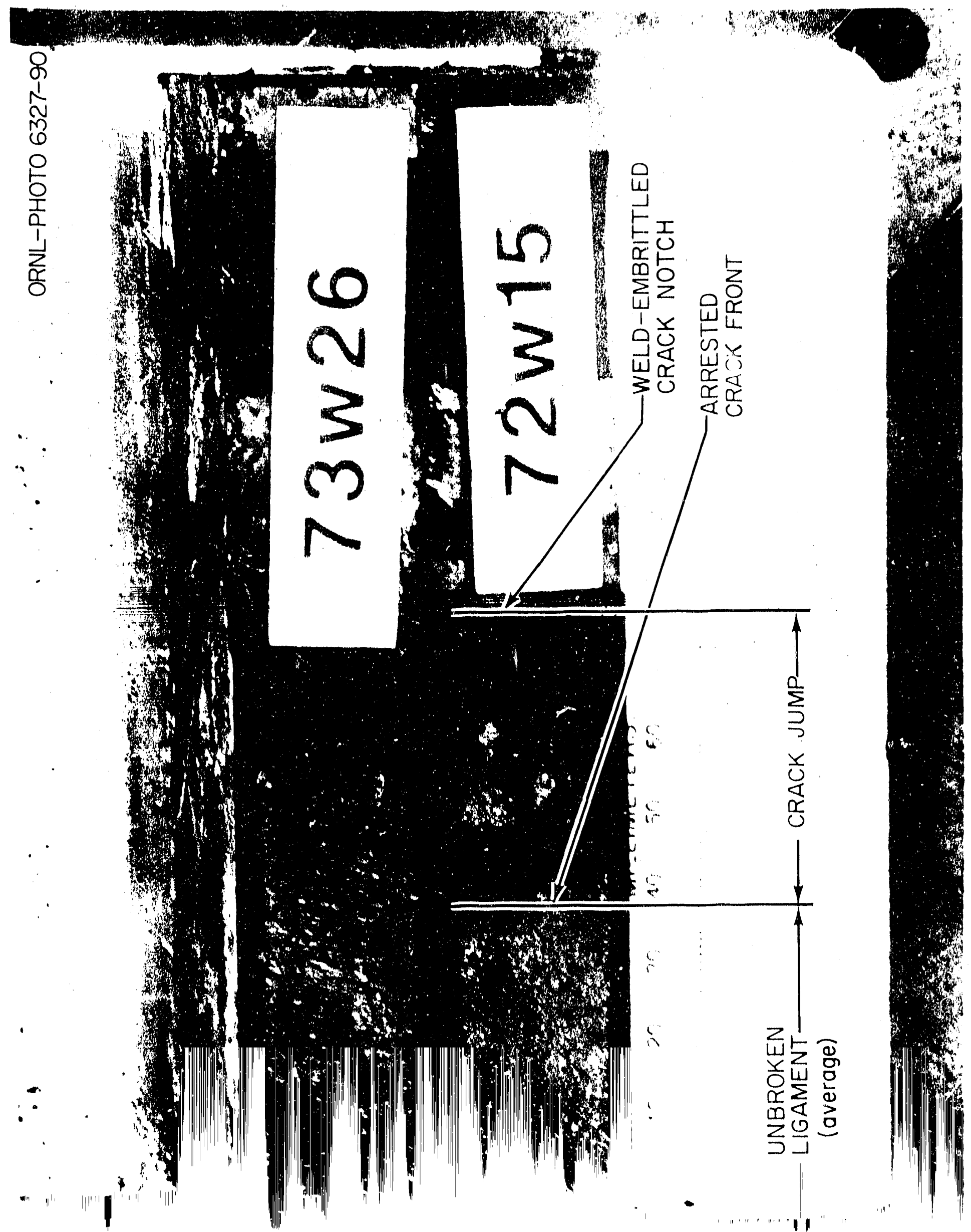




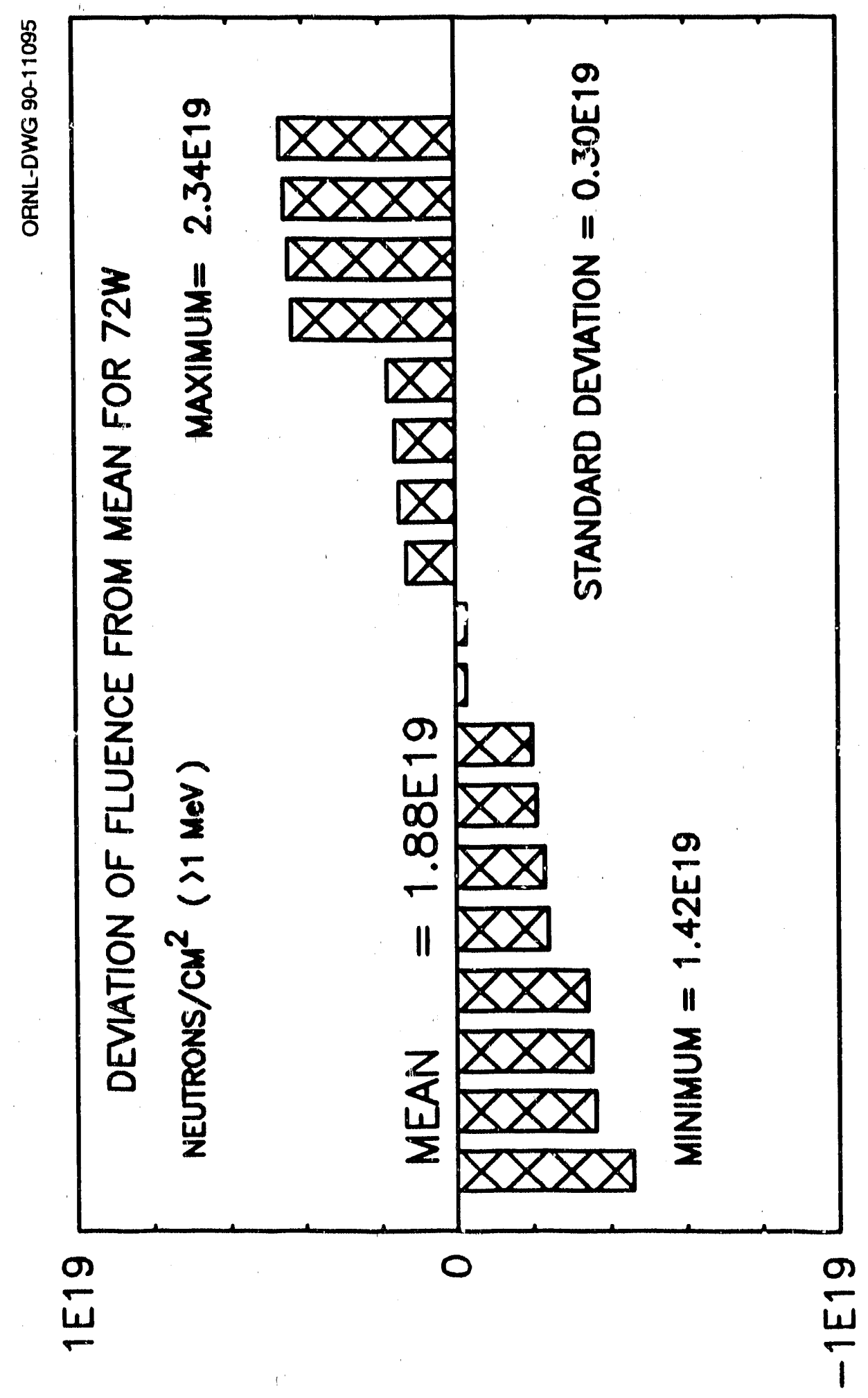

N $\forall \exists W$ WOU」 $\exists O N \exists \cap 7 \unlhd$ JO NOIL $\forall I \Lambda \exists O$ 
ORNL-DWG 90-15463
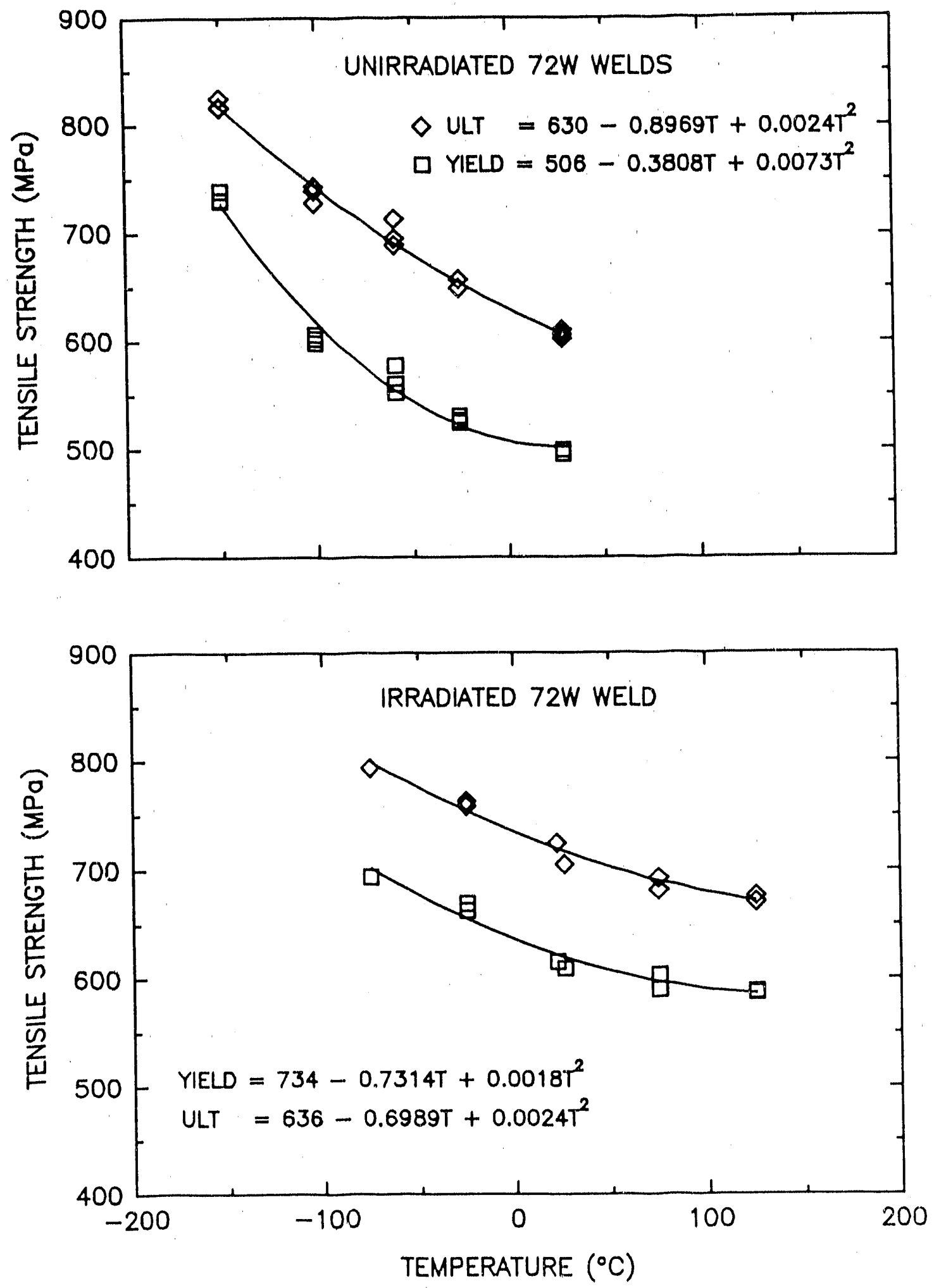

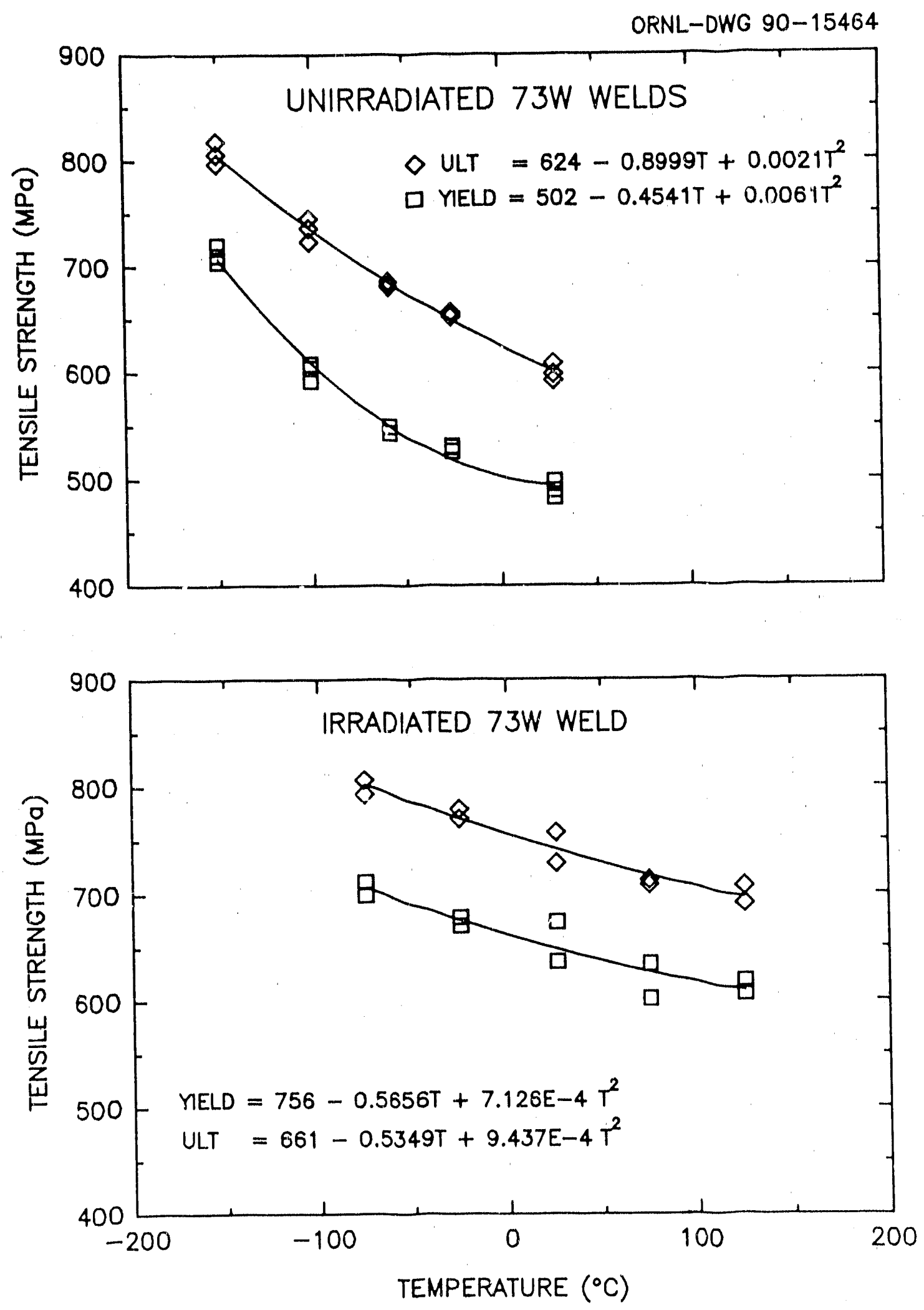


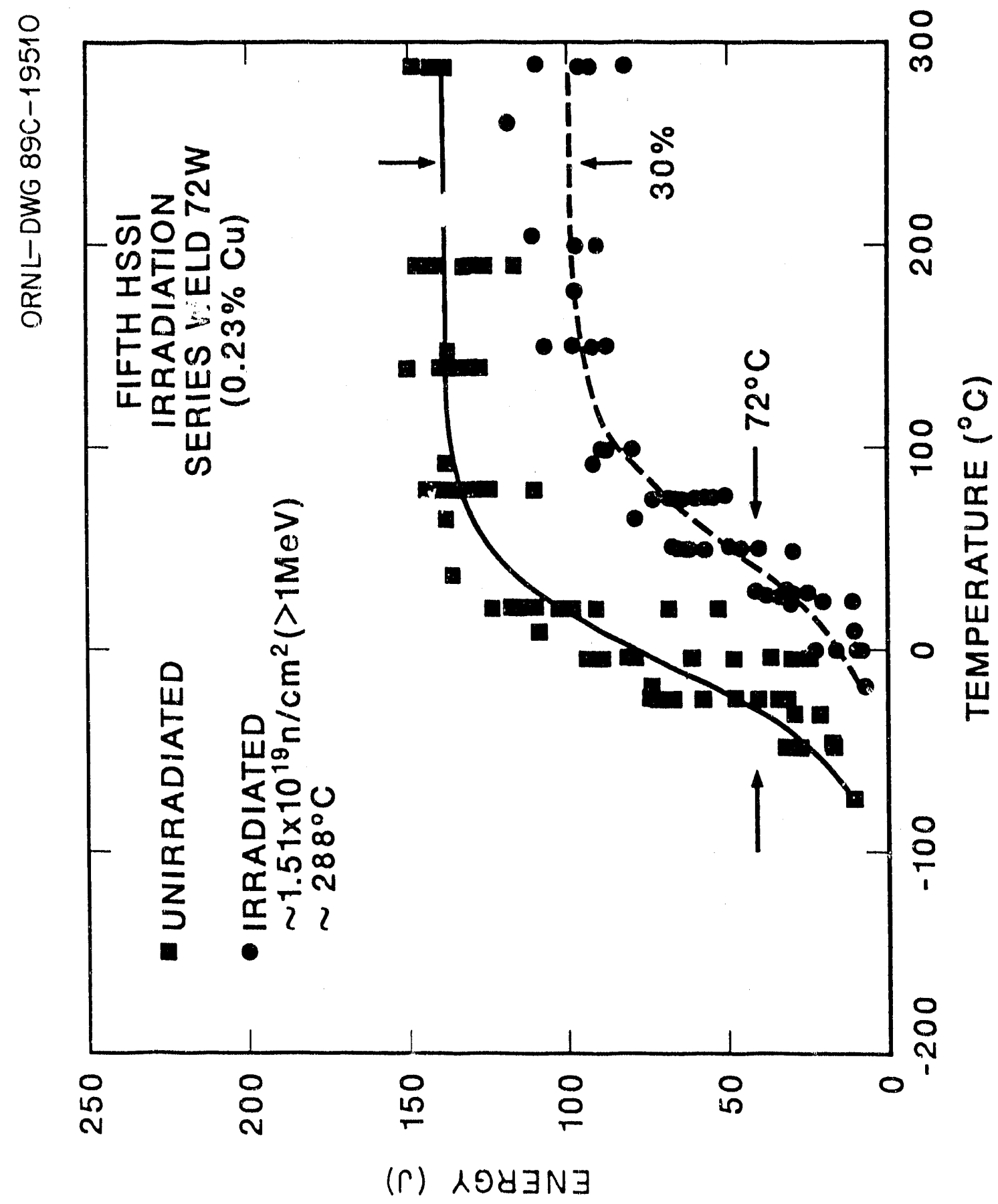




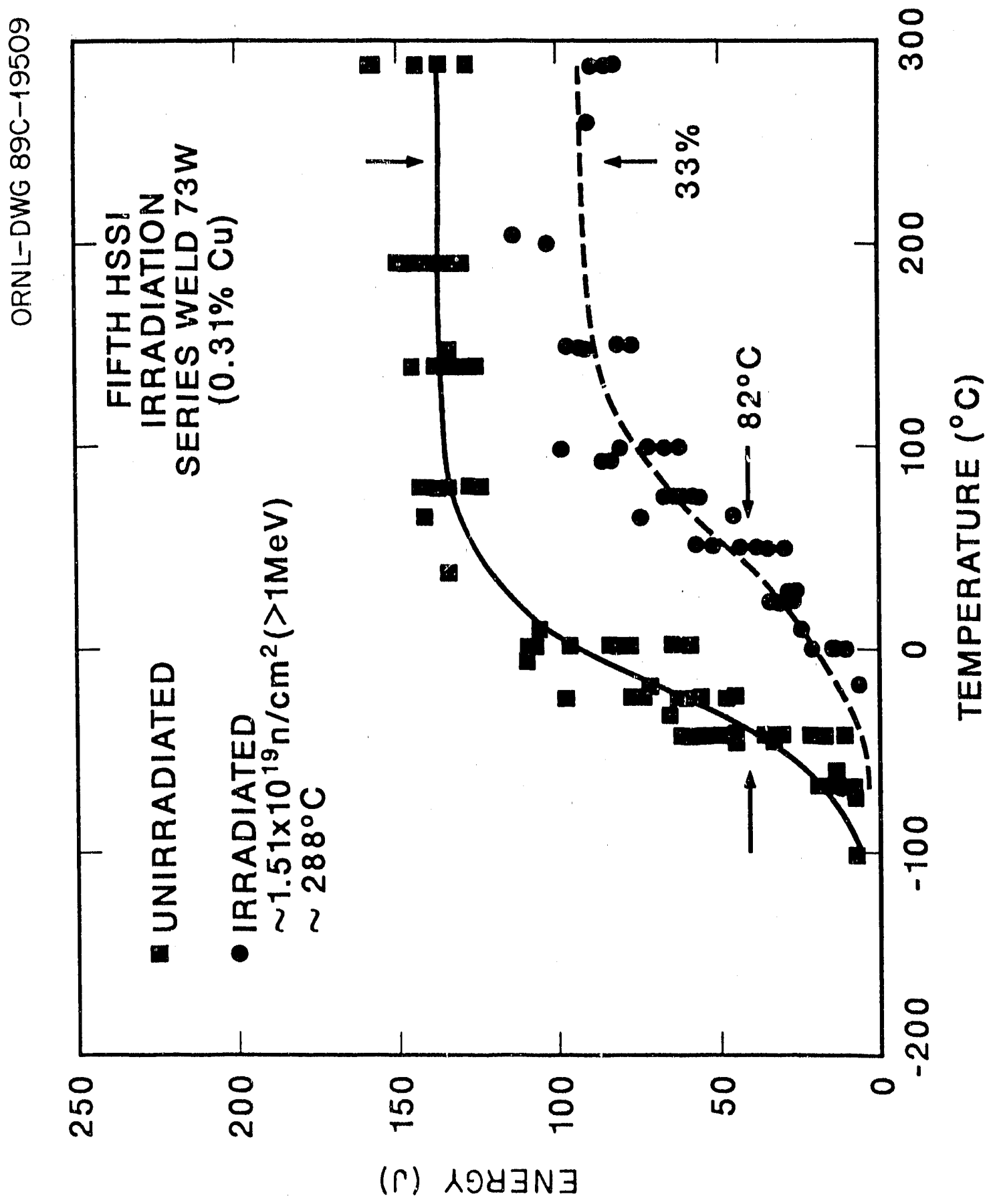




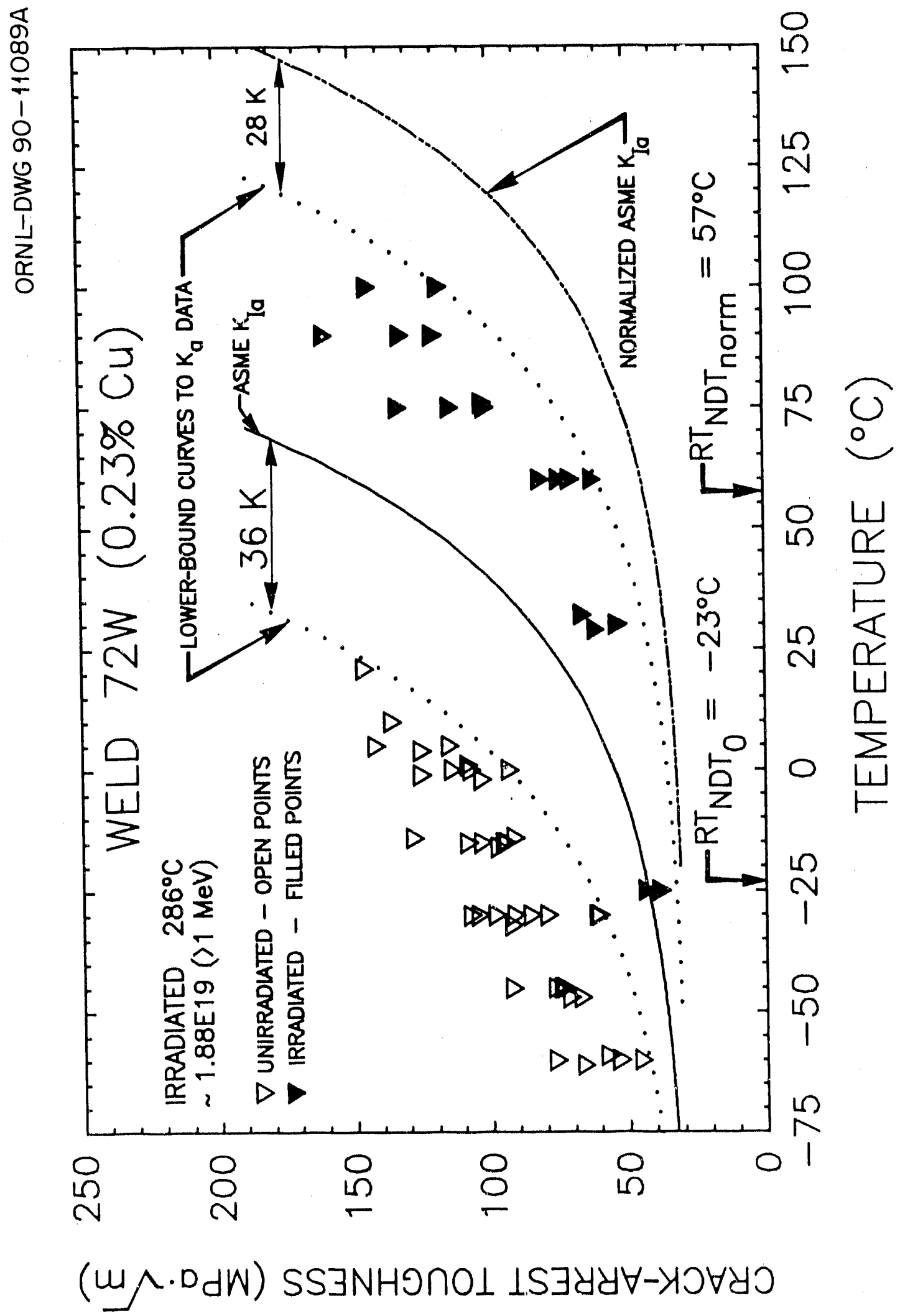




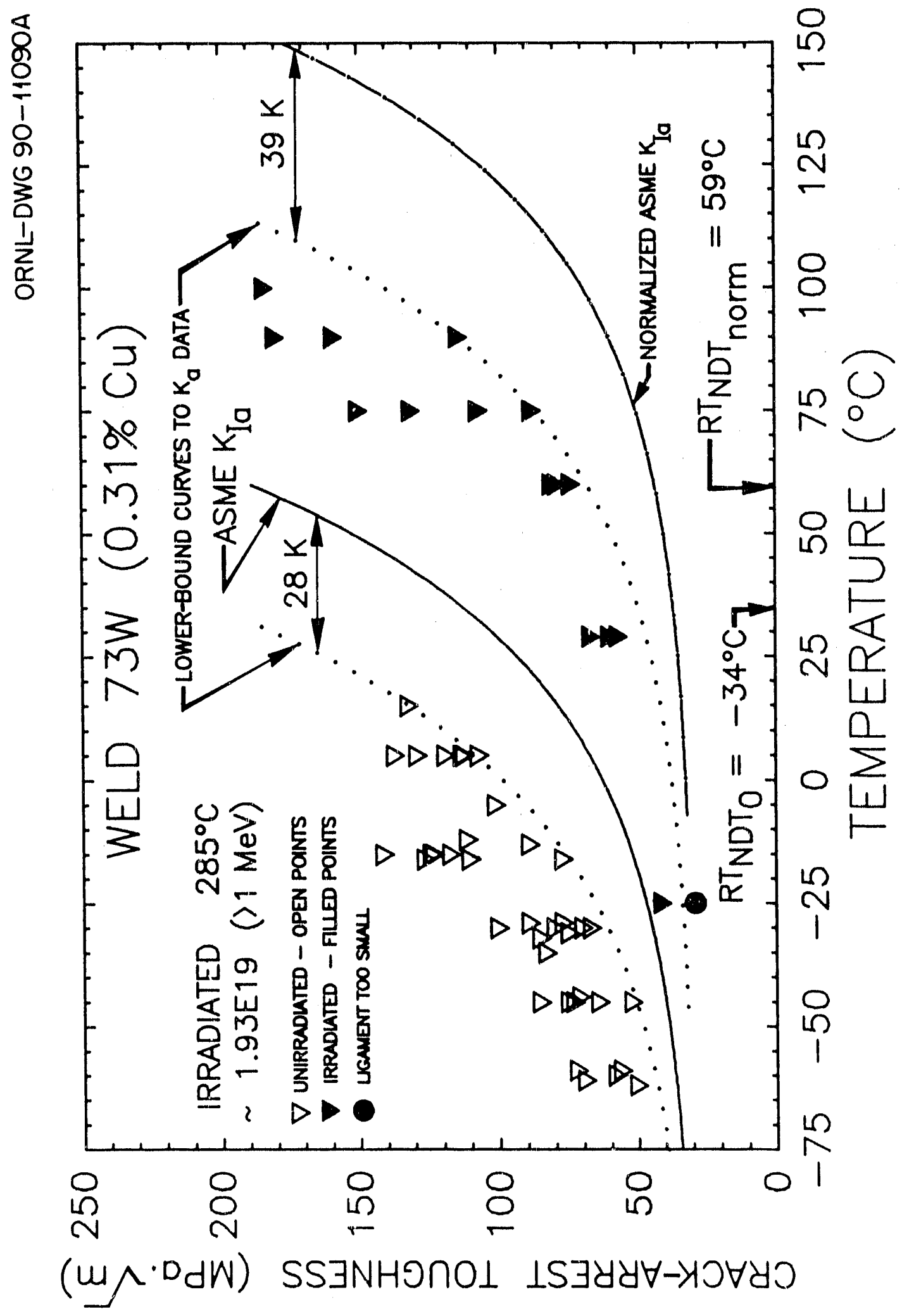



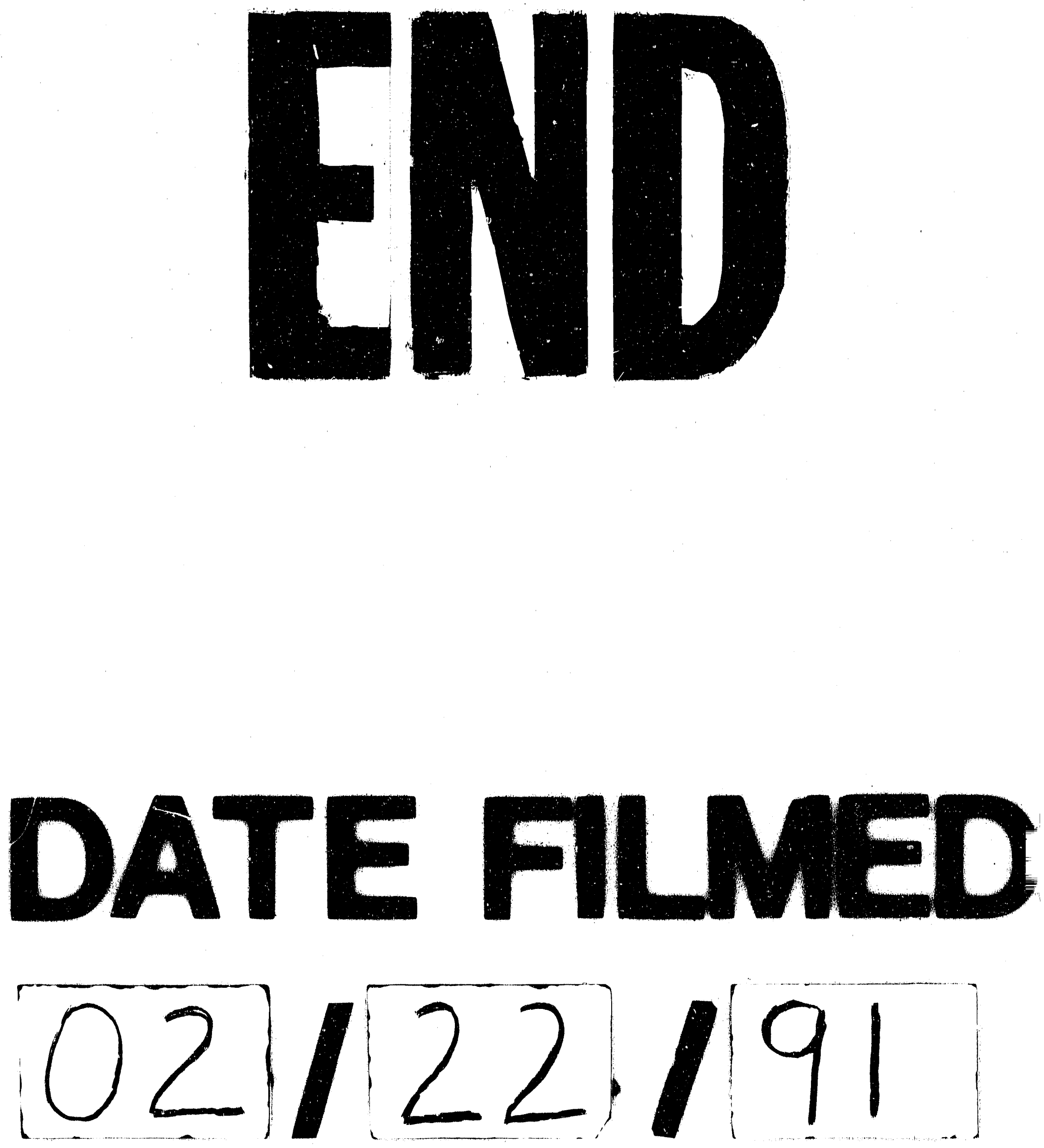
